\title{
"From Death and Despair to Hope": Géricault, Poussin, and Cultural Memory in France
}

\author{
Marijke Jonker
}

In 1816 the French warship Méduse was shipwrecked near the African coast. Because there were not enough lifeboats, some of the crew and passengers had to try to save themselves on an improvised raft, towed by the lifeboats. By order of the captain, the lines were cut when the raft proved to slow down the boats. For days the raft was adrift on the ocean. When it was finally saved, most of the castaways were dead. The news of this event caused a scandal in France. Forces opposing the government had it that after Napoleon's downfall, birth and connections served again to secure officer's rank, just as they had done during the Ancien Régime. Incompetent and despotic officers could once again ruin the lives of their subordinates.

Théodore Géricault's Raft of the Medusa (fig. 1) met with a very mixed reception during the first half of the nineteenth century. In 1819, when it was exhibited at the Salon, Géricault was criticized for choosing an anecdotal subject, with no known national hero as the protagonist, for a painting so large. Its horrifying subject matter was hardly lessened by the fact that the individual figures seemed to be based on the work of famous painters such as Jacques-Louis David, Antoine-Jean Gros, and Pierre Guérin. The painter was also criticized because he had failed to make clear which moment in the sad story of the castaways of the Medusa on their raft was actually depicted. ${ }^{1}$

Géricault died young, in 1824, and during the next twenty-five years his reputation grew. The individualism of many Romantic painters, such as Eugène Delacroix, was believed to prevent the emergence of a new national French school in painting. Under these circumstances, Géricault was increasingly seen as the artist of genius, still close to the French tradition of Poussin and David, who, had he lived, might have been the leader of this school. As opposition to the Restoration Monarchy, and later the July Monarchy, grew, The Raft of the Medusa gained the reputation of a great modern classic, embodying a protest against conservatism in art and politics.

Géricault's painting was explicitly coupled to Nicolas Poussin's achievement by two left-wing intellectuals, especially during the $1840 \mathrm{~s}$. One was the historian Jules Michelet and the other the art critic Charles Blanc. We find Michelet's remarks about Géricault in his diaries from 1829 until the 


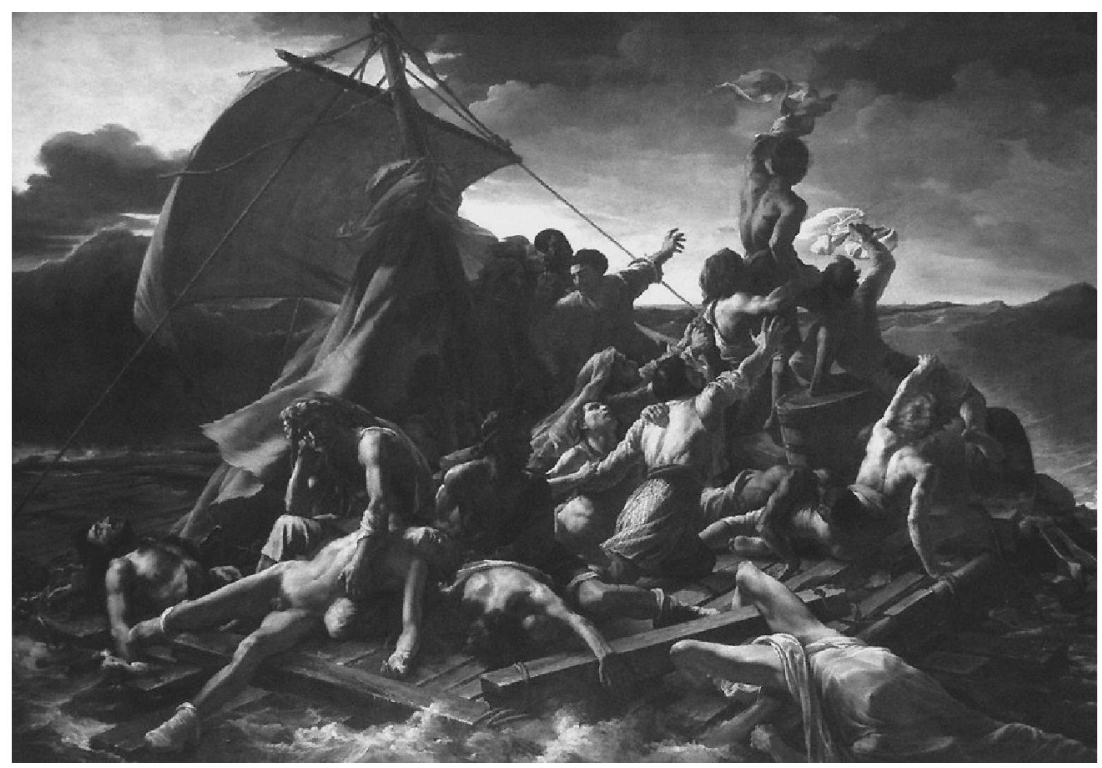

Fig. 1. Théodore Géricault (1791-1824), Le Radeau de la Méduse (The Raft of the Medusa), 1819. Oil on canvas, $491 \times 716 \mathrm{~cm}$. Paris: Musée du Louvre.

1840s and in lectures he delivered at the Collège de France in 1846 and 1848. Charles Blanc, for his part, praised Géricault in his book Histoire des peintres français au XIXe siècle (1845) for sharing Poussin's ability to lend an epic quality to a scene taken from reality. ${ }^{2}$

It should be noted that not just Géricault but also Poussin was regarded as a hero of progress by the French left. The writings of the historian Louis Blanc, Charles Blanc's brother, illustrate this perfectly. In his judgment, the age of Louis XIV, when through Colbert's agency artists and writers had been able to gain respect by serving their country with their art, was an early stage of the Third Estate's rise to power (Louis Blanc 206; StarkFranck 38-39). He considered the Third Estate to be the leading force in modern French history. The nineteenth century was the age in which it truly became the ruling power - only to be superseded finally by the Fourth Estate, the workers. This explains why Charles Blanc, who adopted many of his brother's ideas, was deeply interested in Poussin, his biography and his ideas. Poussin had been practically the first French painter to rise above the status of artisan, to entrust his theory of painting to paper, and to be revered in his own age. 


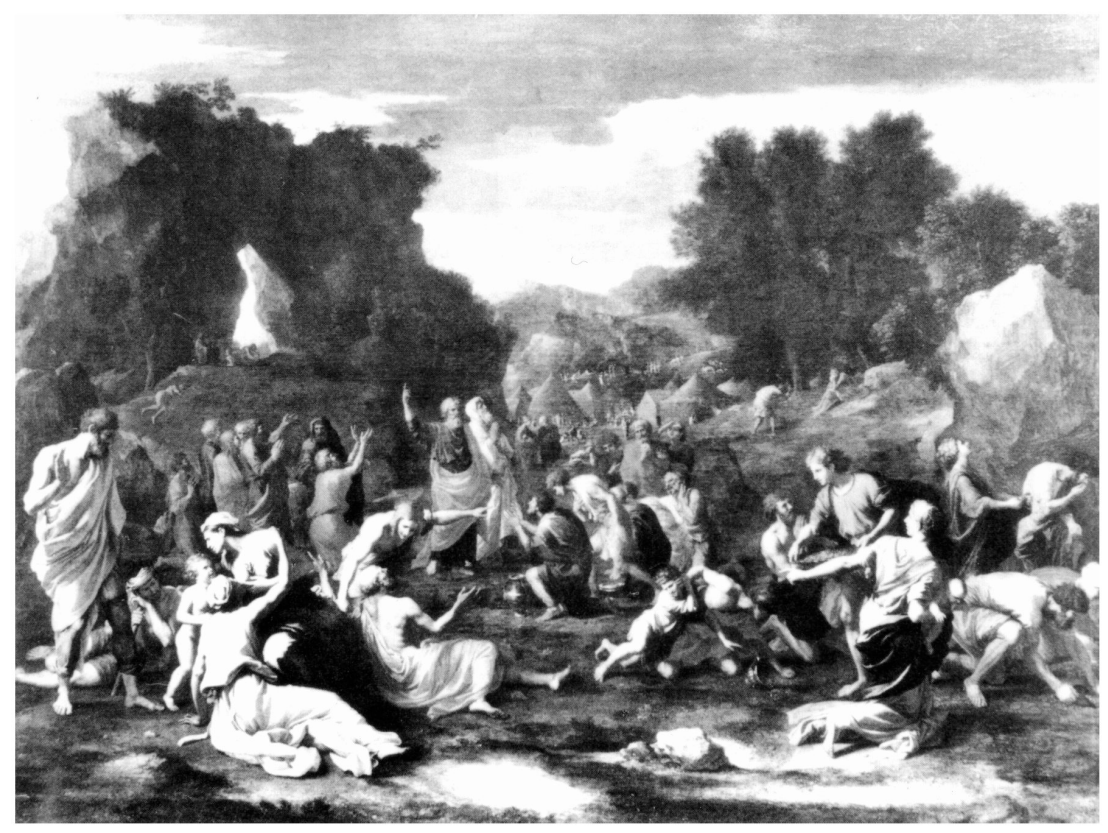

Fig. 2. Nicolas Poussin (1594-1665), Les Israélites recueillant la manne dans le désert (The Gathering of the Manna), 1637-38. Oil on canvas, 149 x $200 \mathrm{~cm}$. Paris: Musée du Louvre.

In their writings about Poussin and Géricault, both Michelet and Charles Blanc showed that they were familiar with the seventeenth-century printed sources on Poussin and his work. One of these is Poussin's letter to his friend and benefactor Paul Fréart de Chantelou, cited in Félibien's Vie de Nicolas Poussin (1688), in which the painter elaborates his theory of the modi. According to this theory, composition, color, lighting, and facial expressions should all be in harmony and in accordance with the mood of a painting's subject (Félibien 56-57). Another source used by Michelet and Blanc was Charles Le Brun's Conférence about The Gathering of the Manna, painted by Poussin for Chantelou in 1637-38 (Mérot 98-112). That painting (fig. 2) was likely acquired for the collection of Louis XIV in 1666. Le Brun's Conférence was one of a series given in 1667 by the members of the Académie Royale de Peinture et de Sculpture about famous works in that collection; they were published in the following year.

Le Brun, Premier Peintre du roi and director of the Academy, used The Gathering of the Manna as an example of the superiority of modern French painting over that of the Italian Renaissance; his underlying aim was to 
prove the superiority of modern France in general. Defending the painting against the criticism that Poussin should have shown only one moment from the story, the happy mood caused by the finding of the manna, he insisted that the painter had to represent in one image both the despondent mood of the Jewish people before the manna rain and the happiness after, so as to convey the meaning of this event more clearly. Le Brun employed a key term from Aristotle's Poetics, the highest authority in literary and artistic matters he could summon, and declared that Poussin had used the manna rain as a peripetia, a turning point in the action of a tragedy, except that in this case it was a dramatic change for the better. The fact that the painting centered on a peripetia explained why it showed such contrasting moods. At the same time, the unity of the painting was safeguarded because the action and attitude of every figure was clearly related to the hopeless situation of the Jewish people and the happy change brought about by the manna rain. This unity was further supported by the harmonious color, lighting, and proportions of all elements in the composition. Le Brun thus presented Poussin as an intellectual artist who had created a magnificent painting based on sound theoretical knowledge.

When we look at The Gathering of the Manna and The Raft of the Medusa and take Michelet's and Blanc's knowledge of seventeenth-century art theory into account, their coupling of Poussin and Géricault is easily understood. Géricault's image of the survivors of the shipwreck of the Medusa, packed together on their makeshift raft, shows them at the very point of expiring. Then all of a sudden, a sail appears on the horizon. Some of the castaways are beyond hope, while others wave frantically at the passing ship. Like Poussin, Géricault depicted the group demonstrating the greatest despair in the lower left-hand corner of his painting. As we have seen, in 1819 critics of The Raft of the Medusa complained that Géricault had chosen the wrong moment. It was not at all clear if the survivors would be saved, or if the ship would sail on without noticing them. Michelet, however, saw clarity where the critics had seen only confusion. In his diary from 1829 he wrote that Géricault's ability to show the transition from death and despair to hope was inspired by Poussin's repetition of effects. ${ }^{3}$ This principle enabled the artist to create paintings in which subject and execution worked together to create harmony and unity. Here we can hear echoes both of the theory of the modi and of Le Brun's lecture.

But Michelet had still another reason for praising The Raft of the Medusa. According to him, the painting symbolized the whole of the French people hopelessly adrift on the ocean, with hope for a better future expressed by the figure waving to the passing ship. This man stood for the century, for ship- 
wrecked France and all its people, refusing to die (Géricault 39-41). Michelet described the painting as a gripping comment on the disastrous history of France between the defeat in Russia and the battle of Waterloo. When, surprisingly, he called the painting a "funerary exodus" ("exode funèbre"), there is an implicit comparison between the sufferings of the French nation and those of the Jewish people, coming out of slavery and traveling through the desert in search of their promised land (Géricault 39). The art critic Charles Blanc also described the painting as a horrific scene illuminated by a ray of hope. For this, he too pointed to the figure of the man who is the first to draw the castaways' attention to the far-away sail. He thought it a particularly fine idea to elevate a black man above the other figures and to the role of protagonist, for "a poor slave will free all these men who have subjected and despised him" ("C'est un pauvre esclave qui va délivrer tous ces hommes qui l'ont asservi et dédaigné": Histoire des peintres français 421). Both interpretations betray the political message that Géricault's work held for the French left; but, as I shall now argue, they also point to similarities between The Raft of the Medusa and The Gathering of the Manna on a deeper level than the theoretical and compositional alone.

The meaning of The Gathering of the Manna is usually considered to have been apolitical and quite accessible to any religious person during the seventeenth century, for it shows the manna rain as a prefiguration of the Eucharist, a meaning ascribed to it since the beginning of Christianity. The Biblia pauperum (Poor Man's Bible) and Speculum humanae salvationis (Mirror of Human Salvation) of the Late Middle Ages widely diffused this typological pairing. During the sixteenth and seventeenth centuries, the Counter-Reformation inspired some of its most powerful depictions (Schlink 82-83). However, there can be little doubt that The Gathering of the Manna was acquired for the royal collection in 1666 for quite another reason: as a symbolic depiction of royal power, believed to be derived from the power of the Almighty himself.

During the reign of Louis XIV and in the writings of Bossuet and other defenders of absolutism, Moses, the lowly herdsman, slow of speech and reluctant to lead, served as a model for absolute, just, and non-despotic leadership. Works of art with Moses showing the Jewish people the will of God by writing down the Law, striking water from the rock, and confronting them with the miracle of manna raining from heaven were greatly sought after during this period. The black slave pointing to the far-away ship in The Raft of the Medusa and, as Charles Blanc observed, illuminated by a ray of hope, is indeed a modern Moses. He is an ordinary mortal unexpectedly elevated above others to lead them and give them hope. 
The figure of Moses had always played an important part in French royal symbolism. The scepter which the kings of France received after their anointment and which designated their judicial power was referred to as the staff of Moses (Jackson 314). Like Moses, the king possessed legislative and punitive powers derived from God; he acted as an intermediary between God and the French people. In Poussin's Gathering of the Manna, Moses is majestically present, pointing heavenward to where the light breaking through the clouds symbolizes the divine presence.

That the painting was admired for the way in which it could be used for royal propaganda is made clear in Le Brun's lecture. His emphasis on the fact that the Jewish people were coming out of danger was a clear reference to the wars and rebellions that had torn France apart during the preceding hundred years. He described the composition and lighting in terms that stressed not only the drama, but also the hierarchic ordering of the painting, an echo of the hierarchic, peaceful ordering of contemporary society guided by the king and the "sovereign light" from above ("une lumière souveraine", Mérot 109). That Poussin intended the painting to be understood in this way is clearly suggested by a letter he wrote to Jacques Stella, also cited in Félibien's biography of the artist:

I have found a certain distribution for M. de Chantelou's painting, \& certain natural attitudes, that show the misery \& hunger to which the Jewish people was reduced, \& also the joy \& mirth that it experiences now, the admiration that it feels, the respect and reverence that it has for its Legislator, with a mixture of women, children \& men of different ages $\&$ temperaments, things, I believe, that will not displease those able to read them well. ${ }^{4}$

The biblical and royal symbolism of The Gathering of the Manna becomes even clearer when we cast a glance at some of the other paintings discussed in the famous Conférences of 1667 . The series opened with a lecture about Raphael's Saint Michael Slaying the Dragon, painted in 1518-19 for the pope and presented to François I shortly after. The archangel Michael is the guardian angel of France, and the dragon stands for France's enemies. Apart from giving his name to the Ordre de Saint-Michel, created in 1469 by Louis XI, Saint Michael is also the Christianized version of Apollo, the sun god, protector of peace, science, medicine, and art, a figure at the heart of Louis XIV's royal propaganda. With their favorable review of this painting by Raphael, the epitome of the court artist, the members of the Academy angled for royal protection.

Other paintings explicated in the Conférences depict scenes from the life of Christ and his death and resurrection. These paintings were seen to symbolize the immortality of kingship, which survives the death of the king's 
mortal body. Examples are Titian's Entombment (ca. 1520), a Holy Family by Raphael (1518), and Veronese's Supper at Emmaus (1559-60), showing Christ's appearance in full glory to his disciples after his resurrection.

Poussin's Christ Healing the Blind (1650) refers to a belief that came close to equating the kings of France to Christ while elevating them above all other kings because of their anointment with the Saint chreme. This oil had supposedly been brought from heaven by a dove when the heathen king Clovis was baptized in 499, a vision that made the baptism of Clovis a re-enactment of Christ's baptism in the river Jordan. After they were anointed, the French kings were supposed to possess healing powers, a sure sign of their having been chosen by God, on a par with Christ and Moses, Christ's Old Testament type. ${ }^{6}$ The manna rain as a prefiguration of the Eucharist took on a specific meaning in the anointment ritual, the sacre. An anointed king of France shared the right of priests to partake of both bread and wine during Holy Communion. He exercised this right only once, on the day of his sacre (Bloch 205).? Indeed, the French kings were so deeply convinced of their sanctity that they even wished to have the sacre recognized as the eighth sacrament, something to which Rome, of course, never consented.

During the seventeenth century, when Louis XIII and Louis XIV established absolute kingship, the sacred, Christ-like character of kingship became an ever more important feature of royal propaganda. The Grande Galerie of the Louvre was the place where, during the seventeenth century, on the most important Christian holidays, the king touched sufferers of scrofula, the disease he was supposed to be able to heal (Bloch 361). It is no coincidence, then, that Chantelou, the original owner of The Gathering of the Manna, tried to persuade the government for many years to have this painting, together with others by Poussin depicting scenes from the life of Moses, copied as tapestries for the Grande Galerie.

Much of the symbolism of the king's anointment must have been familiar to Blanc, Michelet, and their readers, since it had been part of Napoleon's imperial propaganda and the ritual had continued to be performed until 1825, at the sacre of the last Bourbon king, Charles X. Around that time the comparison of royal power with that of Moses cropped up again in Royalist writings. Indeed, the theme of Moses, with all its judicial and religious connotations, remained popular during the first half of the nineteenth century, with artists and writers both defending and attacking royal power. Liberals did not hesitate to represent Moses as the founder of constitutional government. ${ }^{8}$

But the ultimate reason for the kinship recognized between The Raft of the Medusa and The Gathering of the Manna is found in a belief that was closely tied up with royal propaganda and lay at the heart of the sense of identity of 


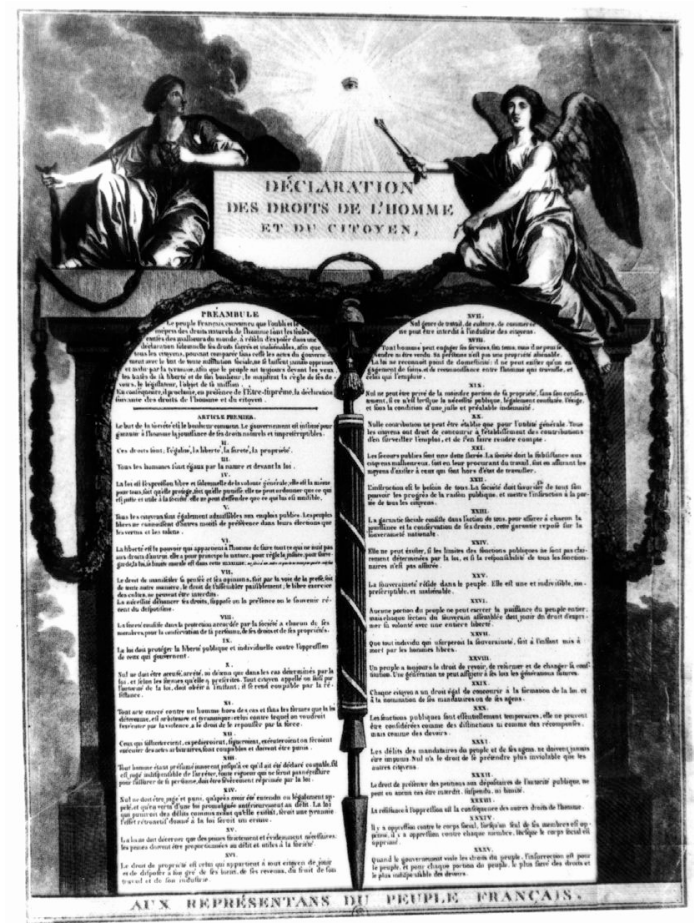

Fig. 3. Louis Laurent (active in early 19th c.) after JeanJacques-François Lebarbier (1738-1826), Déclaration des droits de l'homme et du citoyen (Declaration of the Rights of Man and Citizen), ca. 1789 . Etching, $53 \times 39 \mathrm{~cm}$. Paris: Bibliothèque Nationale.

the French people. The equation of the French king with Moses cannot be fully explained by the propagandistic needs of absolute kingship alone. Rather, the French believed that as their king was chosen by God, the French were consequently the modern chosen people, successors to the Jewish people in this role. This faith inspired much of the Old Testament imagery conspicuous during the French Revolution, such as the many depictions of mountains and law tables. In depictions of the Déclaration des droits de l'homme et du citoyen, the text is written on law tables (see fig. 3). In contemporary descriptions of the mountains used in revolutionary celebrations, the mountain was described as a modern Mount Sinai, where God made his will known to Moses (Joutard 533, Mosser 24-25, Ribner 6-28). The presence of biblical imagery during 


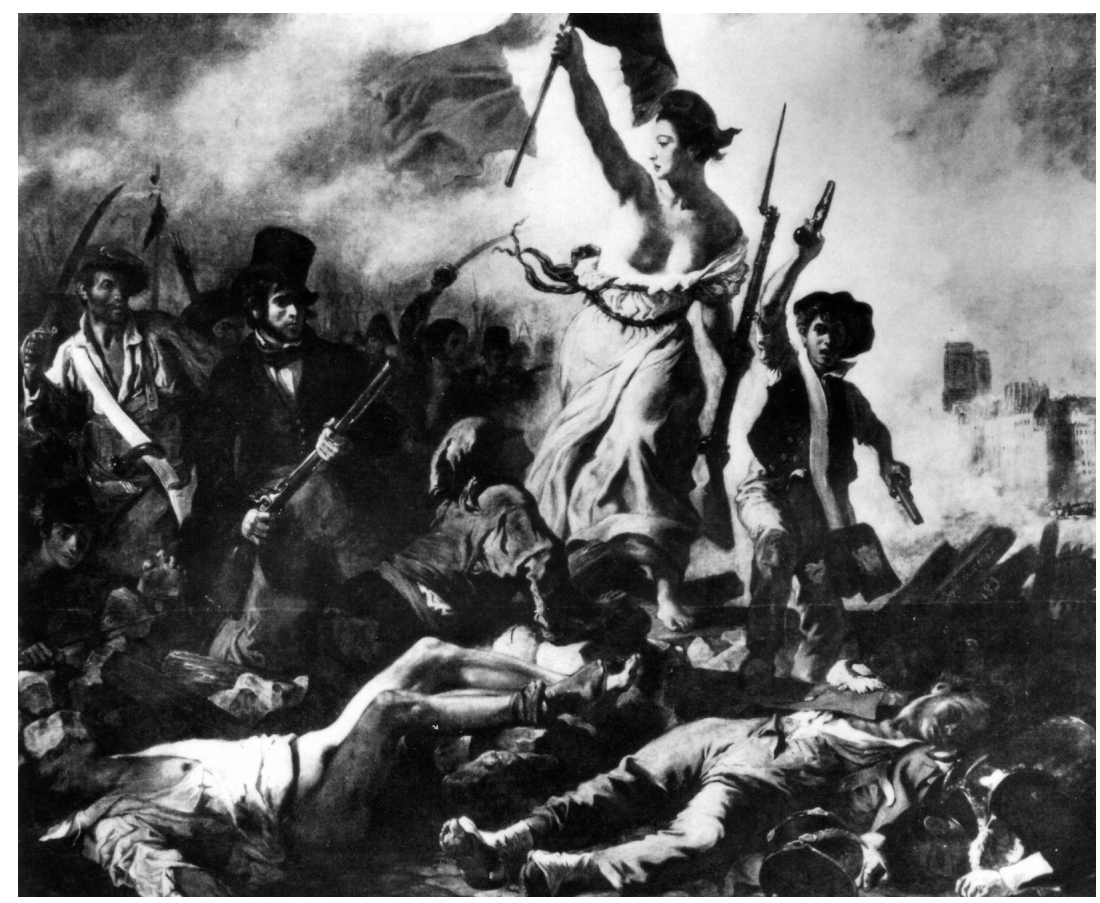

Fig. 4. Eugène Delacroix (1798-1863), La Liberté guidant le peuple (Liberty Leading the People), 1831. Oil on canvas, 417 x 354 cm. Paris: Musée du Louvre.

the Revolution proves that the faith in the French as the chosen people could survive the destruction of kingship. Post-Revolutionary and post-Napoleonic historians wrote their histories of modern France still fully supporting this idea. France had given the Revolution and Napoleon to the world, and for this reason, the fate of France was the fate of the world (Joutard 543).

Michelet's interpretation of The Raft of the Medusa as a depiction of the French nation hopelessly adrift on the ocean becomes much more accessible when seen in this light. The despair felt by the French and the glimmer of hope that still existed signified that these modern chosen people, destined to lead the world to a better future, had not lost the ability to save themselves and thereby save the world. Michelet believed that in place of the monarchy, the French people constituted the most important force in French history. Time and again, leaders had emerged from the people and stepped forward to change the destiny of France. These figures had not always been male. Michelet's view of women as the most important regenerative force in society seems 
to echo French Revolutionary and post-Revolutionary imagery, in which a male figure, symbolizing royal power, was replaced by a female one, symbolizing the people, the Republic. For Michelet, Joan of Arc, led by heavenly voices that made the will of God known to her, was the most important figure in French history. Like Moses and the black slave in The Raft of the Medusa, she was an unlikely person to be moved to center-stage. Michelet considered her both a female Messiah and the embodiment of the struggle of the French people for national identity. Far more than the king, it was Joan of Arc who, in a nearly hopeless situation, had stood at the cradle of the modern French nation (Crossley 216). Her "voices" told her that she should convince the king to have himself anointed. Michelet must have been aware of the equation of the proletarian girls who fought on the July barricades with Joan of Arc, a metaphor that crops up in reports of the July days. ${ }^{9}$ Delacroix's image of one of these girls, looking like a Republican goddess of liberty and brandishing a banner like Joan (see fig. 4), may have also stirred Michelet's imagination.

Even more than Charles Blanc, Michelet must have understood both The Gathering of the Manna and The Raft of the Medusa as depictions of the French people who, seemingly lost beyond hope, never perish, embodying the hope for a brighter future for France and for the world. Like The Gathering of the Manna, and in spite of contemporary criticism, The Raft of the Medusa was a perfect French history painting, a narrative of the reversal from despair to hope in the dramatic history of the French people.

\section{NoTES}

1 See L'Indépendant, Landon and Clément 163-71 for criticism of the painting's theme and composition, and Eitner 46-47, 59-60 for criticism concerning the artistic influences visible in the painting.

2 See Fauquet for a survey of Michelet's and Blanc's writings about Géricault and Poussin.

3 "Répéter les effets disent Poussin, Lesueur. C'est ce qu’a exécuté Géricault: deux lignes de la mort et du désespoir à l'espérance" ("Repetition of effects, say Poussin, Lesueur. This is what Géricault has executed: two lines from death and despair to hope": Michelet, Ecrits 246). All translations are mine.

4 "J'ai trouvé ... une certaine distribution pour le tableau de Mr. de Chantelou, \& certaines attitudes naturelles, qui font voir dans le peuple Juif la misere \& la faim où il étoit réduit, \& aussi la joye \& l'allegresse où il se trouve, l'admiration dont il est touché, le respect $\&$ la reverence qu'il a pour son Legislateur, avec un mélange 
de femmes, d'enfans \& d'hommes d'âges \& de tempéramens differens, choses, comme je crois, qui ne déplairont pas à ceux qui les sçauront bien lire" (Poussin, qtd. in Félibien, 27-28).

5 For the use of this series of paintings for royal propaganda, and its religious context, see also Held and Mérot 60, 81.

6 For good surveys of the sacre and its meaning see Bloch and Simon.

7 Louis Marin (251-60) has argued that both The Gathering of the Manna and the other paintings discussed in the 1667 Conférences represented royal power in a different way than French seventeenth-century royal portraits. Portraits of Louis XIV were meant to personify the king and his power. Through a mystical process resembling the Eucharist, they became the king, in the same way in which this sacrament changes bread and wine into the body and blood of Christ. History paintings narrated the Biblical history and mystery in which the royal power was rooted, and for this reason viewing these paintings can be compared to reading, as is implied by Poussin himself in his letter to Stella.

8 See Ribner's survey of this subject.

9 "Une jeune fille, nouvelle Jeanne d'Arc, combattit à la place de la Bourse avec une valeur extreme" ("A young girl, a new Joan of Arc, fought at the Place de la Bourse with exceptional courage"), An. (qtd. in Agulhon, 58).

\section{SOURCES CITED}

Agulhon, Maurice. Marianne au combat: L'Imagerie et la symbolique républicaines de 1789 à 1880. Paris: Flammarion, 1979.

Blanc, Charles. Histoire des peintres français au dix-neuvième siècle. Vol. 1. Paris, 1845.

Blanc, Louis. Histoire de la Révolution française. Vol. 1. Bruxelles, 1847.

Bloch, Marc. Les Rois thaumaturges: Étude sur le caractère surnaturel attribué à la puissance royale particulièrement en France et en Angleterre. 1924. Paris: Colin, 1961.

Bossuet, Jacques-Bénigne. Politique tirée des propres paroles de l'Écriture sainte. 1709. Ed. Jacques Le Brun. Geneva: Droz, 1967.

Clément, Charles. Géricault: Étude biographique et critique avec le catalogue raisonné de l'ouvre du maître. Paris, 1868.

Crossley, Ceri. French Historians and Romanticism: Thierry, Guizot, the Saint-Simonians, Quinet, Michelet. London, New York: Routledge, 1993.

Eitner, Lorenz. Géricault's Raft of the Medusa. London, New York: Phaidon, 1972. 
Fauquet, Eric. "Le Géricault de Michelet." In Géricault. Ed. Régis Michel. Vol. 2. Paris: La Documentation française, 1996. 759-75.

Félibien, André. Lettres de Nicolas Poussin: Précédées de la Vie de Poussin. 1688. Paris: Wittmann, 1945.

Held, Jutta. Französische Kunsttheorie des 17. Jahrhunderts und der absolutistische Staat: Le Brun und die ersten acht Vorlesungen an der königlichen Akademie. Berlin: Reimer, 2001.

L'Indépendant, 29 August 1819: 3.

Jackson, Richard A. "The Traite du Sacre of Jean de Golein." Proceedings of the American Philosophical Society 113 (1969): 305-24.

Joutard, Philippe. "Une passion française: L'Histoire." In Les Formes de la culture. Vol. 3 of Histoire de la France. Ed. André Burguière and Jacques Revel. Paris: Seuil, 1993. 511-70.

Landon, Charles-Paul. Salon de 1819. Vol. I. Paris, 1819.

Marin, Louis. Le Portrait du roi. Paris: Minuit, 1981.

Mérot, Alain, ed. Les Conférences de l'Académie royale de peinture et de sculpture au XVII siècle. Paris: École Nationale Supérieure des Beaux-Arts, 1996.

Michelet, Jules. Écrits de jeunesse: Journal (1820-1823), Mémorial, Journal des Idées. Ed. Paul Viallaneix. Paris: Gallimard, 1959.

—. Géricault. Paris: L'Échoppe, 1991.

Mosser, Monique. "Le Temple et la montagne: Généalogie d’un décor de fête révolutionnaire." Revue de l'art 83 (1989): 21-35.

Ribner, Jonathan P. Broken Tablets: The Cult of the Law in French Art from David to Delacroix. Berkeley: U California P, 1993.

Schlink, Wilhelm. Ein Bild ist kein Tatsachenbericht: Le Bruns Akademierede von 1667 über Poussins Mannawunder. Freiburg/Breisgau: Rombach, 1996.

Simon, Patrick. Le Mythe royal. Diss. U Lille III, 1987. Paris: Aux amateurs de livres, 1987.

Stark-Franck, Käte. Louis Blanc als Historiker der französischen Revolution. Diss. U Hamburg 1934. Zeulenroda: Sporn, 1935. 